\title{
UM PRECURSOR DO COMÉRCIO FRANCÊS NO BRASIL
}

\section{GALLES' E SEU LIVRO}

No decorrer de estudo a que procediamos, há uns dois anos, na Biblioteca do Ministério da Fazenda, sôbre assunto em que, por dever de ofício, andávamos entāo empenhados, deparamos com pequena brochura, que despertou nossa maior curiosidade. Associado seu título à data da impressāo, era deveras de surpreender tal livro numa época em que é bem pobre a bibliografia, nāo só nacional como estrangeira, sôbre a matéria de que se ocupa o autor, cujo nome era para nós completamente desconhecido.

E a sua leitura em breve nos convenceu da importância da obra para o estudo das relações comerciais entre a França e o Brasil, após o restabelecimento da paz na Europa em 1814. E, provàvelmente, pelo teor quase didático de suas informaçóes, muito terá ela concorrido para a intensificaçāo do comércio entre os dois paises.

Intitula-se o livro, numa prolixidade bem ao gôsto do tempo: “DU BRÉSIL, OU OBSERVATIONS GÉNÉRALES SUR LE COMMERCE ET LES DOUANES DE CE PAYS, SUIVIES D'UN TARIF DE DROITS D'ENTRÉE SUR LES MARCHANDISES FRANÇAISES, ET D'UN TABLEAU COMPARATIF DES MONNAIES, POIDS ET MESURES".

Publicado em Paris, em dezembro de 1828, foi seu autor Ed. Gallès, nome que se encontra acompanhado dos seguintes atributos: "Membre de plisieurs sociétés d'instruction, et Subrécargue arrivant du Brésil".

Assim, ainda mal assinados estavam os primeiros convênios de comércio entre o Brasil e as principais potências européias, após - reconhecimento de nossa independência política, quando aquêle livro, que tem noventa e três páginas in $80^{\circ}$, foi escrito. $E$ suas observações, que nāo se limitam, apenas, ao terreno mercantil, como seu nome parece indicar, estendem-se, e năo raro com singular agudeza, ao panoraxa social, politico e religioso do país.

Embora o trabalho de Ed. Gallès fique muito aquém da conhecida obra que seu compatriota, Horace Say, escreveu onze anos 
depois - "Histoire des relations commerciales entre la France et le Brésil" - não pode deixar de nos parecer estranho o silêncio que em tôrno dele até hoje se fêz. Na verdade, o nome de Ed. Gallès encontra-se ausente nāo só do texto como da bibliografia das mais importantes obras sôbre o Brasil, nas quais o seu testemunho a respeito dos usos e costumes da época em que aqui esteve seria, talvez, tão valioso quanto o de outros estrangeiros que por aqui também andaram(1).

E releva notar que êsse nāo foi o único trabalho que Gallès escreveu sôbre nosso país - sua segunda pátria, como mais tarde diria - parecendo mesmo, pelo material que conseguimos coligir, muito haver feito em meados do século passado para o estabelecimento de uma linha de navegação regular entre a França e o Brasil, como tentaremos demonstrar.

Não obstante a indiferença ou desconhecimento, por circunstâncias fortuitas talvez, que parece ter envolvido "Du Brésil", que se encontra incluido, porém, na importante "Bibliographie Brésilienne", de A. L. Garraux, bem como na "Biblioteca Exótico-Brasileira", de Alfredo de Carvalho, aquêle livro, como se vê das transcrições que se estendem por quinze páginas que o acompanham, numeradas fora do texto, foi objeto de calorcsa recepçāo por parte da imprensa francesa da época(2).

O "Journal de Commerce de Paris", de 16 de dezembro de 1828, comentava: "O comércio da França com o Brasil assumiu, nos últimos anos, grande extensāo; muitas operaçōes têm fracàssado, no entanto, por falta de conhecimentos práticos sôbre os artigos que convém àquêle pais, sôbre o seu regime aduaneiro, sôbre uma porção de pequenas coisas, enfim, que, em conjunto, concorrem mais do que se pode imaginar para o bom êxito das expediçöes. A obra que acaba de publicar o Snr. Ed. Gallès, subrécat-

(1). - O único autor no Brasil. em que vimns referência a Galles e ao livro de que ora tratamos, $e$ Adolfo Morales de los Rios Filho, em seu importante traballo "O Rio de Taneiro Impcrial". onde "Du Brésil" aparece citado, a págs. 409, entre as obras que cram cncontradas nas livrarias e alfarrabistas de antanho.

Na. Franca. as observações de Gallès são invocadas, mais de uma vez, por Ferdinand Denis. em seu livro "Le Brésil". Paris. 1837.

(2). - O fichário da Biblioteca Nacional do Rio de Janeiro acusa a existencia de dois exemplares desta obra. Mas sempre que os pedimos as requisicoes nos foram devolvidas com a seguinte nota: "Fora de lugar". N possivel que. de longa data. essa venha sendo a informação dada a todos quantos tenham procurado tomar conherimento do livro. Não deixa cle ser significativo o fato de "Du Brésil" näo constar do "Cat́́logo da Exposição de Fistória do Brasil", realizada por aquela Biblioteca em dezenibro de 1881, onde, entretanto, vem mencionado livro posterior de Galles, de bem menor importancia, a qual nos reportaremos, oportunamente, neste trabaho. 
gue (3) recem-chegado do Brasil, contém preciosas informações a éste respeito. $\bar{E}$ um trabalho que o tornará credor do reconhecimento dos armadores e a respeito do qual pretendemos voltar a ocupar-nos. Chamamos, por enquanto, a atençāo de nossos leitores para o minucioso título da obra, prevenindo-os de que êle nāo indica tudo quanto de útil se encontra nesta publicaçāo."

Bem mais longa é a apreciaçāo do "Journal du Havre", de 20 do mesmo mês. $O$ articulista comprazeu-se, porém, em respigar as informações menos lisongeiras existentes no livro de Gallès, principalmente sôbre certas práticas dos funcionários de alfândega de entāo, para tecer alguns comentários bem azedos a respeito do Brasil. Entendia, assim, que a obra era de um homem que sabia escrever e dum comerciante que tinha visto muito, de olhos abertos. Lamentava, apenas, que o autor tivesse abusado algo das imagens laudatórias, na longa página com que depõe seu trabalho sob a aza protetora de Balguerie Júnior, pessoa, como se deduz, de importância no quadro político e social da época(4).

"Nas circunstâncias atuais", escrevia o "Indicateur de Bordeaux", de 24 de dezembro de 1,828, "tudo que se relaciona com - Brasil deve excitar a curiosidade pública $e$ o interêsse do comércio. A França descurou-se tanto dêste pais, o qual oferece nāo só recursos como mercados imensos à nossa indústria, que hoje devemos assenhoriar-nos, com avidez, de tôdas as matérias que lhe digam respeito". Julgava, dêsse modo, que "Du Brésil" bem merecia os elogios que lhe haviam feito os jornais da capital, nāo duvidando de que o Ministro do Comércio, o que era confirmado pelas lisongeiras cartas que o autor dêle havia recebido, se apressaria a adquirir tal obra, indispensável às principais câmaras de

(3). - "subrecargue, s.m. (de l'espagnol sobrecarga); forme de sobre, sur, et carra, charge). Agent special nomme par les armateurs pour veiller a la conservation et a la vente des marchandises qu'ils ont chargées, pour en acheter d'autres destinees au retour et recevoir le fret. attributions qui d'ordinaire appartiennent au capitaine" (Dictionnaire La Chatre. Paris).

o têrmo correspondente em português é sohrecarga, embora o Código Comercial Brasileiro. de 1850 . na parte em que se ocupa do comércio martrimo. dêle não faca usn.

Jose da Silva Ijsboa. visconde de Caiurú, escrevia: "Ientre nós se distinguem as trís funçoes de Mestre, Sobrecarca b Piloto, ainda que podem combinar-se e simultaneamente achar-se no mesmo sujeito. conforme a extensão da ordem ou comissão do dono do navio. O Mestre \& pròpriamente o encarregado do costeio, carga, aprovisionamento, expedicão, economia e descarga do navio no lugar do destino. onde finda a viagem do ajuste, nāo podendo ingerjr-se em compra e disposição de efeitos de comércio. Sobrecarga é aquêle que é verdadeiramente posto sobre a carga. sendo-lhe cometida pelo proprietário on armador do navio a negociacño, que faz o objeto da viagem, e que tem em conseqiiẹncia o direito de cobrar os fretes e fazer todas as operaçóes e despesas convenientes; o que nāo pode fazer o Capiț̃o simples na presenca do dito proprietário ou s.rmador, ou do correspondente, e consignatários destes a quem representa" "Principios de Direito Mercantil e Leis de Marinha para uso da mocidade portuguésa, destinada ao comércio" Tratado IV, pág. 53. Lisboa, Impressão Régia, 1S19).

(4). - Tista tendência pare render homenarem, so nūo aos poderosos, pelo menos ao poder constituido, representado pelo que tinha de mais aristocrático, parece-nos que foi um dos traços acentuados do caráter de Ed. Galles, como esperamos evidenciar no prosente trabalho. 
comércio do Reino. E, paternalmente, acrescentava: "Coragem. Snr. Gallès! Eelo, em vossa idade, já ter títulos que vos tornam merecedor do reconhecimento público".

O articulista de "Kaléidoscope", de 1 de janeiro de 1829. traçava, em primeiro lugar, algumas normas aos que, em viagem. quizessem fixar suas impressões. "Se nāo conheceis suficientemente o desenho", dizia êle, "tomai uma pena e descrevei os objetos no mesmo instante em que ferirem vosso olhar. As impressões que êles então vos causarem serāo as únicas exatas, as únicas que deveis transmitir a vossos leitores; outras quaisquer irão é enganá-los". E isto para ponderar: "O Snr. Ed. Gallès seguiu, quase sempre, êste sábio preceito no pequeno volume que acaba de publicar, e sentimo-nos felizes em poder anunciar que estas notas sôbre os. costumes e os hábitos brasileiros sāo, em geral, de grande exatidão, nāo porque elas se encontram de perfeito acôrdo com o que dissemos a respeito dêste rico pais em nosso "Promenade aut-tour du monde", mas porque as curtas páginas que acaba de oferecer ao público nos transportaram de novo àquêle solo prenhe dos tesouros de uma natureza tāo generosa mas tāo negligenciada". Embora pudéssem ser apontados alguns erros no livro, que năo tinham, a seu ver, qualquer importância, julgava-o indispensável aoß comandantes de navios que não conheciam o Brasil. E prosseguia: "Eles (os comandantes de navios) nāo têm outra coisa a fazer senāo guiar-se pelos coṇselhos que lhes sāo dados, pois se livrarāo de muitos aborrecimentos, além de pouparem aos seus comitentes muitas despesas inúteis. Jamais agenda alguma foi tāo rica em documentos assim preciosos e nāo utilizá-los é correr o risco de perdas certas. O Snr. Gallès tem direito ao reconhecimento do comércio." E referindo-se, finalmente, ao estilo da obra como "conciso, exato, cheio de calor", asseverava que o seu autor pensava como negociante e escrevia como publicista (5).

"Le Propagateur" nāo podia demonstrar maior apreço pelo trabalho de Galliès do que o fèz em sua critica de $10^{\circ}$ de janeiro. de 1829: "Guiado pelos mais louváveis sentimentos, nosso jovem compatriota, Snr. Gallès, publica, sob o título "Observações", os dados e fatos que coligiu durante sua viagem ao Brasil: apressamo-nos em recomendar a nossos leitores esta importante obra, que contém coisas verdadeiramente úteis para o comércio e que traz

(5). - Graças ao título do livro - "Promenade autour du monde" - de que o crítico de Gallès se diz autor. foi-nos possivel estabelecer sua identídade, e esta empresta, sem dúvida, maior valor àquela apreciação. Trata-se de Jacques Arago, de famosa familia, o qual tomou parte na viagem de circumnavegação feita a bordo da corveta "Urante". de 1317 a 1821. sol o comando de Louis de Freycinet. Foi quando esteve no Frasil. aonde voltou posteriormente. Escreveu "Promenade autour du monde". a que se seguiu "Vovage autour du monde", que teve várias edicóes. "Viveu em Bordeaux, onde fundou "Kaléidoscope". Alem de jornalista emerito, foi fecundo escritor teatral, embora atacado de cegueira. Nascido na Franca em marco de 1799. morreld em janeiro de 1855. ao desembarcar pela quinta vez no Brasil ("La Grande Encyclopédie", de Berthelot). 
a marca dum espírito observador e dum patriotismo esclarecido. Devem ser levadas a crédito do autor as numerosas pesquisas que foi obrigado a realizar, para obter os curiosos conhecimentos e as informações precisas que contém sua publicaçāo; ela se tornará, com certeza, um guia indispensável a todos aquêles que mantêm relações comerciais com o Brasil e que desejam ser esclarecidos sôbre os passos a dar e os inconvenientes a evitar. As descrições de Pernambuco, Bahia e Rio de Janeiro serāo lidas com grande interêsse, mas o que sobretudo nos parece digno de apreço sāo os pormenores escrupulosos que o autor fornece a respeito das alfândegas do país que acaba de visitar, pormenores cujo conhecimento, doravante, se torna essencial a todos quantos desejem operar sôbre bases seguras e pôr-se ao abrigo dos contratempos, que a ignorância dos fatos nāo raro acarreta". Ao publicista, entretanto, pareceram exagerados, também, os epitetos elogiosos de que se acha repleta a dedicatótia a Balguerie Junior, os quais nada juntavam. aos titulos de estima que possuia aquêle cidadāo. Discordava o jornalista, ainda, de algumas opiniões de caráter político e filosófico que Ed. Gallès avançara, o que, porém, não o impedia de julgar que o seu jovem compatriota, que fazia jús ao reconhecimento público, acabava de prestar um verdadeiro serviço a sett país.

Sem restrições de qualquer natureza era a análise da "Revue Commerciale et Maritime" (6), também de $1 .^{\circ}$ de janeiro de 1829. "Observações cheias de sabedoria e elevação, apreciações extremamente justas, conselhos destinados a prestar ótimos serviços, dados estatísticos plenos de interêsse, eis o que notamos, com prazer, no escrito do Snr. Ed. Gallès", dizia o crítico. E acrescentava: "O autor nāo obteve por correspondência as descrições e documentos que nos apresenta; nem foi do recesso de seu gabinete que visitou os portos do Brasil: êle tudo viu, tudo julgou por si próprio. Se nos oferece particularidades do comércio, da administração, dos direitos alfandegários dêste país, foi a pêso de ouro e após mil pesquisas que as poude conseguir; se nos associa aos usos, aos hábitos dêstes longínquos lugares, é porque os estudou conscienciosamente". E o articulista reconhecia que para avaliar jbra de tal gênero forçoso seria transcrevê-la quase por inteiro. Limitava-se, pois, a resumi-la em breves linhas, concluindo: "Demos nossa opiniāo com franqueza, primeiro dever do homem que pretende julgar outro; já felicitámos sinceramente o Snr. Gallès pelo verdadeiro serviço que acaba de prestar ao comércio; desejamos felicitá-lo, ainda, predizendo, sem receio de nos enganar-

(6). - A crítica da. "Revue Commerciale et Maritime", bem como as duas anteriores de "Kaleidoscope" et "Le Propagateur" näo trazem indicacão da cidade em que êstes orgãos eram publicados. Com referência a "Kaléidoscope". vide nota 5 . 
mos, que sua obra passará a ser o vade mecum indispensável de todos que se ocupem com expedições maritimas".

Esta série de críticas é, finalmente, encerrada com uma carta, datada de 16 de dezembro de 1828, dirigida ao autor de "Du Brésil", na qual, acusando o recebimento de seu trabalho, o Ministro do Comércio da França prometia lê-lo com grande interêsse. certo de que o valor da obra o levaria a adquiri-la "para tôdas as câmaras de comércio do reino".

Terāo os críticos de Ed. Gallès sido excessivamente pródigos na apologia de seu livro, admitindo mesmo que alguns dêsses louvores, que têm o matiz de sermāo encomendado, houvessem decorrido da interferência pessoal do autor? Parece-nos que nāo, se considerarmos que se tratava, talvez, da primeira obra que surgia na França a dar informaçôes nítidas e amplas, com um espírito essencialmente prático, a respeito das possibilidades comerciais de um pais, para onde se voltavam os olhos ávidos da Europa.

Dos vários livros publicados até 1828 sôbre o Brasil, após a abertura de seus portos ao comércio direto estrangeiro, destacam-se os dos viajantes inglêses, como John Mawe ( 7 ), Henry Koster, nascido, aliás, em Portugal(8), James Henderson(9), Gilbert F. Mathison(10), Maria Graham(11), Alexander Caldcleugh(12), John Luccock (13), ao lado dos quais se colocam os naturalistas germânicos Spix e Martius (14) e o Principe Maximiliano de Wied (15). $\mathrm{Na}$ França apresentam-se, no mesmo periodo, Hippolyte Taunay

(7). - John Mawe - "Vjagens ao interior do Brasil principalmente ans distritos do curo e dos diamantes", Londres 1812. Traducão de Solena. Benevides Viana, com introdução e notas de. Clado Ribeiro de Lessa, Rio de Janeiro, 1944.

(8). - Henry Koster - "Viagens ao Nordeste do Brasil", Londres. 1816. Traducão e notas de Luiz da Câmara Cascudo, São Paulo, 1.94.2.

(9). - Tames Fenderson - "History of the Brazil, comprising its Geography, Commerce, Colonization..." T.ondres. 1821.

(10). - Gilbert F". Mathison - "Narrative of a Visit to Brazil, Chile, Peru and the Sandwich Islands", Londres, 1825.

(11). - Maria Graham - "Journal of a Vorage to Brazil and Residence there during part of the years $1821,1822,1823^{\prime \prime}$, Londres, 1824.

(12). - Alexander Caldcleugh - "Travels in South America during the years 1819-20-21". Londres. 1825.

(13). - John Luccock - "Notas sôbre o Rio-de-Janeiro e partes meridionais do Erasil", Londres, 1820. Tradução de Milton da Silva Rodrigues, São Paılo. 1942

(14). - Joh. Bapt. Von Spix e C. F'. Phil. Von Martius - "Travels in Brazil in the years 1817-1820". "Tradução inglesa de H. E. Llard, Londres, 1824 .

(15). - Maximiliano. Príncipe de Wied-Nerwied - "Viagem ao Brasil nos anos de 1815 a 1817", Frankfurt, 1820. Tradução de Iddgar Sussekind de Mendonca e Flavio Poppe de Figueiredo, refundida e anotada por Olivếrio Pinto, São Paulo, 1940. 


\section{DU BARSAL.}

ot

\section{OBSERVATIONS GÉNERALES \\ SUR LE COMMERCE}

ET LES DOUANES DE CE PAYS,

SUIVIES

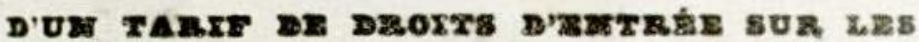

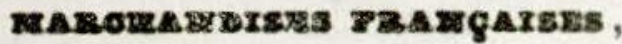

$$
\text { ยร จ'เæ }
$$

Tableau comparatif des Monnaies, Poidget Mgums:

$$
\text { PAR ED. GALLES, }
$$

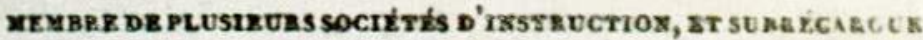

Arrivant du Brésil.

Didice à Atb. Balqueric jusnion.

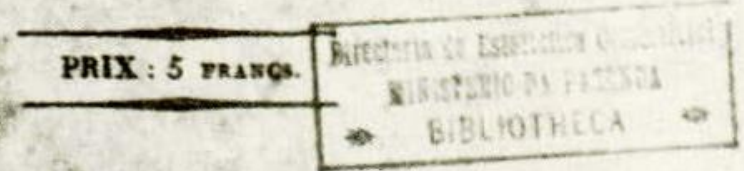

\section{PA RIS,}

a la librairie dU COMmerce, CHEE RENARD, LIBRAIRE, QVE EALXTE-Asmz, $x^{0} g x$.

Oécenture 18 a 8 .

Fig. 1, 


\section{DU BRÉSIL,}

OU

\section{OBSERVATIONS GÉNÉR ALES}

SIR LA DOUANE ET LE COMMERCF.

DE CE PAIS.

\section{INTRODUCTION.}

Les ressources et le débouché extraordinaires que présentent les différens ports du Brésil au commerce français; les besoins toujours croissans de ce vaste empire, tant de nos produits agricoles que manufacturiers; les richesses intarissables de son sol, l'immensité des trésors que la nature s'est plu à prodiguer sur ces terres encore vierges; la consommation presque incroyable qui,pourrait s'y effectuer de nos vins et spiritueux, si le négociant connaissait d'une manière précise et physique le goùt et ie palais brésiliens;

Les pertes effrayantes auxquelles sont exposées les maisons qui se destinent à exploiter ces 
e Ferdinand Denis(16), Louis de Freycinet(17), Jacques Arago(18). Anglievel la Beaumelle(19), além do Barāo de Rous$\sin (20)$ e de Alphonse de Beauchamp, com sua história do Brasil, em três volumes(21). Auguste de Saint-Hilaire(22) mal fizera entrever, então, o que seriam suas extraordinárias publicações sôbre nosso pais, em anos subseqüentes.

Todos êsses autores, alguns dos quais inteiramente absorvidos por suas pesquisas de caráter cientílico, mal se detiveram em considerações sôbre o cómércio exterior do Brasil e práticas a êle inerentes, com exceçāo de John Mawe e John Luccock, que dispensaram maior atençāo ao assunto, embora sob o ponto de vista britânico. - Não poderiam tais livros, portanto, exercer acentuada influência na França sôbre o ânimo dos que pretendessem estender seu campo de açāo ao novo entreposto da América. E nem mesmo de grande auxilio lhes poderia ser o trabalho de Anglievel La Beaumelle, nāo obstante seu prometedor título: "De l'Empire du Brésil considerée sous ses rapports politiques et commerciaux". $\mathrm{Na}$ verdade, as informações de La Beaumelle, sem maior importância em relaçāo às possibilidades de intercâmbio comercial de sua pátria com o Brasil, eram meramente accessórias dentro do plano geral do livro.

Mais esclarecedor seria, sem dúvida, apesar de seu pequeno volume, o opúsculo que veio a intitular-se na traduçāo portuguêsa: "Documentos relativos ao Commercio dos novos Estados da America, comunicados pela Secretaria Principal do Commercio de França às principais Camaras do Commercio do Reyno, vertidos em lingua vulgar" (23). Discorre êste folheto sôbre as condições comerciais do México, Colombia, Perú. Chile e Brasil, indicando as mercadorias que a França poderia mandar com boas perspectivas de lucro para o nosso país, e que eram "modas, jóias, móveis preciosos, chapeus, sapatos, sêdas de tôdas as qualidades e uma imensidade de outros artigos". Mas tratando-se de um comunicado oficial às "principais Câmaras do Comércio do Reino", não pode deixar de causar espécie, diga-se de passagem, esta sua observaçāo: "Também nos pódiamos fazer senhores do abasteci-

(16) - Hippolyte Taunay e Ferdinand Denis - "Je Brésil ou Histoire. Mocurs, Tisages et. Coutumes des Hahitans de ce Royaume". Paris. 1822.

Ferdinand Denis - "Rósumé de l’histoire du Brésil suivi du Résums de l'histoire de La Guyane". París. 1825.

(17). - Louis de Freycinet. - "Voyage autour du monde", París, 1.827.

(18). - Tacciues Arago - "Promenade autour du monde", Paŕs, s/d. (Tide nota. 3).

(19): - Anqlievel La Beaumolle - "De l'Empire du Jirésil considerte sous ses ravports politiques et commerciaux", Taris, 1823.

(20). - Albin B. Roussin - "Le Pilote du Brésil ou Description des Cotes de Pamerique Meridionale..". Par!s, 1828

(21). - Aịhonse de Beaurhamp - "Histoire du Erésil, depuis sa dócouverte en 7 inn jusqu'en $1810^{\circ}$, Paris, 1815.

(22). - Auguste de Saint-Hilaire - "Apercu d'un voyage dans l'interieur du I3rasil. la Province Cisplatine et les Missions dites du Paraguay", Paris, 1823 .

(23). - Lishoa. Impressão Régia, 1826, 48 páginas. Exemplar existente na Eiblioteca Nacional do Rio de Janeirn. 
mento dos vinhos, porque está provado que os da Frovíncia do Languedoc podem fàcilmente passar por vinhos do Pôrto, por meio de uma breve preparaçāo; e isto havendo a precauçāo de os transportar en pipas de construçāo semelhante às das pipas portuguêsas: porém se esta emprêsa se cometesse era preciso contentar-se, no princípio, com um pequeno lucro". Outras informações dá ainda a mesma publicaçāo a respeito do comércio francês com o Brasil, bem como sôbre "tarifas e regulamentos mercantis", mas tôdas elas nāo ocupam mais de sete de suas páginas.

Nāo é de estranhar, assim, o entusiasmo com que foi recebida na França a obra de Ed. Gallès que, no gênero, parece que nāo encontrava outra com que pudesse ser comparada.

Escrito em linguagem que denuncia em seu autor desenvoltura intelectual, que nāo seria corriqueira num homem de negócios, "Du Brésil" procura ser algo mass do que simples repositório de áridas informaçóes comerciais. Jovem ainda, quando de sua estada no Brasil, segundo dão a entender os críticos de seu livro, mas pertencendo já a "diversas sociedades de instruçāo", Ed. Gallès, contemporâneo de Lamartine, Victor Hugo, Chateaubriand, Saint-Beuve, Benjamin Constant, nāo deve ter vivido, indiferente, os anos agitados da Restauraçāo, da luta entre o absolutismo e o liberalismo. E natural, pois, que tanto o houvessem impressionado as condições sociais do Brasil, arrancando-lhe frases grandiloqüentes de revolta as ceras de escravos que presenciara. Mas seu depoimento sôbre outros aspectos do país, embora demonstre atilado senso de observaçā̄o, nāo deixa de pecar, às vêzes, por parcialismo ou conhecimento menos seguro do assunto de que trata.

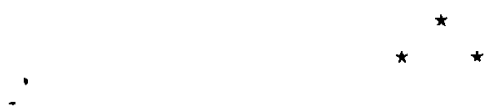

Gallès, na introduçāo de seu livro, esclarece: "Treze meses passados na capital e em outros portos do Brasil, no exercício de importantes operações, bem como as relações que em virtude de minha posição era eu obrigado a manter com as notabilidades do pais, deram-me ensejo de conhecer tôdas as dificuldades que cercam o comércio dêste império, podendo acrescentar que o material que consegui colher, para erigir meu frágil edifício, nāo se obtém senāo a pếso de ouro e à custa de muito trabalho". Deve êle, portanto, ter chegado ao Brasil em meados ou fins de 1827, uma vez que seu trabalho foi publicado em dezembro do ano seguinte, logo após seu regresso à França.

"Du Brésil", como já observamos, foi dedicado, em longo e untuoso panegírico, a Balguerie Junior, nome de tantas virtudes e tão enaltecido pela voz pública, diz Gallès, "que chega a ser distinguido pela confiança diplomática dos monarcas do outro hemisfério, parecendo à França industrial e politica que tal nome deve 
andar à frente de tudo quanto diga respeito ao comércio, às ciências e à administraçāo".

$\mathrm{Na}$ verdade, o nome Balguerie encontra-se intimamente ligado à hịstória do comércio maritimo da França. Pierre BalguerieStuttemberg, nascido em Bordeaux em 1779 e falecido em 1825 , descendia de um comerciante que tinha perdido quase tôda sua fortuna na revoluçāo de São Domingos, e foi, por sua vez, industrial e homem de comércio de largos vôos. Firmada a paz na Europa, após a queda de Napoleão, Pierre Balguerie, ampliando extraordinàriamente seu campo de atividades, armou os primeiros navos que fizeram reaparecer o pavilhäo francês nos portos da China e da India. Promoveu grảndes obras, como a construçāo ou acabamento de vários portos na Frarça, entre os quais o de Bordeaux, o de Libourne e o de Bergerac. Fundou importantes indústrias e foi diretor da caixa econômica e do Banco de Bordeaux. conselheiro municipal e membro do conselho de comércio. Tal foi a importância de seus empreendimentos que Luiz XVIII fê-lo cavalheiro da Legiāo de Honra, tendo um dos bairros de sua cidade natal sido batizado com o seu nome(24).

Se a biografia de Pierre Balguerie-Stuttemberg n⿳亠丷⿵冂o esclarecesse que êle fôra pai de três filhas apenas, seriamos levados a crer que Balguerie Júnior, a quem Ed. Gallès tantos louvores cantou, era seu filho. Mas nāo erramos, provàvelmente, em admiti-lo como seu parente próximo, sobrinho talvez, ou irmāo. E embora Gallès nada esclareça a êste respeito, nāo será demais concluir que stia viagem ao Brasil foi realizada por conta de alguma das emprêsas de Bordeaux, fundadas por Pierre Balguerie-Stuttemberg.

Ao iniciar-se a leitura de "Du Brésil", dá-nos seu autor logo "a impressão de um homem realmente experimentado nas lides de sua profissão. Vejamos como êle justifica o aparecimento de seu livro: "Os recursos e a capacidade extraordinária de absorçāo que oferecem os diversos portos do Brasil ao comércio francês; as necessidades sempre crescentes dêste vasto império, tanto de nossos produtos agrícolas como manufaturados; as riquezas inesgotáveis de seu solo, a imensidade dos tesouros que a natureza prodigalizou a estas terras ainda virgens; o consumo quase inacreditável que ai poderiam ter nossos vinhos e espirituosos, se o negociante conhecesse de um modo preciso e material o gôsto e o paladar dos brasileiros; as perdas assustadoras a que estāo sujeitas as casas que se dedicam a explorar estas paragens, sem noções exatas

(24). - "Ja Grande Incyclopedie", de Berthelot, s/d, a "Biographis Iniverselle Ancienne et Moderne ou Dictionnaire de Tous les IIommes", Bruxelas, $1843-47$. 
e com o desconhecimento de suas necessidades; os gastos exorbitantes que podem ser evitados, possuindo-se dados certos e concatenados a respeito do país; as dificuldades que há em encontrar-se na França êsses elementos, baseados na experiência e boa fé; os vexames alfandegáriós de que se é vitima, quando se ignoram os meios de atenuá-los ou de repelí-los pelo direito; os atrazos, sempre prejudiciais, que sofrem os capitāes que desconhecem as disposições das leis aduaneiras; uma imensidade, enfim, de importantes considerações de economia comercial, o desêjo e a convicção de ser útil a meus concidadāos ou a alguns amigos apenas, bem como os conselhos das principais casas comerciais do Havre e da capital decidiram-me a escrever estas reflexões".

E ao dar conta de seu propósito, esperava Gallès que seu modesto trabalho, como êle o classifica, pudesse chamar a atenção de pena mais experimentada, pois uma obra bem escrita sôbre êste assunto, que tivesse certa divulgaçāo, estaria destinada a' desempenhar um fim moral, esclarecendo os consignantes de seus direitos e dando aos consignatários das mercadorias a obrigaçāo de cumprirem dignamente seu mandato. Tremera ao pensar que "uma diferença de gôsto ou de côr seria o suficiente para arruinar um pequeno comerciante de pacotilha, uma casa, uma família, uma' sociedade industrial", para nāo falar das catástrofes que poderia acarretar um têrmo mal empregado num contrato de fretamento. Como a emigração dos franceses para o Brasil se tornava dia a dia mais considerável, nāo só os viajantes como os capitāes e os armadores dos navios tinham necessidade de ser devidamente crientados. "A França", acrescenta Gallès, "descuidou-se por muito tempo do comércio com o Brasil e ainda hoje desconhece sua importância, porquanto o descaso com que sāo organizados nossos corregamentos para aquelas regiões bem demonstra que ainda nāo nos apercebemos das vantagens que oferecem à nossa balança comercial".

E, realmente, quem lucrara com tal descaso fôra a Inglaterra, a qual gozava, aliás, desde 1810 , de favores alfandegários que só em 1826 a França havia conquistado, como remate das negociações para o reconhecimento da independência do Brasil.

Mas nāo foi, pròpriamente, o volume do coméricio inglês com o nosso país que mereceu especial reparo do autor de "Du Bré"sil"; o que êle não deixava de acentuar é que, enquanto a França permanecia de olhos vendados, a Inglaterra já tinha estabelecido aqui companhias, que extraiam tesouros incalculáveis das lavras de Minas Gerais.

Nāo fôra, assim, sem propósito, prosseguia Gallès, que "o aulor da Carta (Luiz XVIII), o qual, como Montesquieu, tinha idéias tāo amplas quanto exatas sôbre as necessidades das nações, e cujo olhar penetrante sabia divisar o futuro", havia ordenado, em 1820, uma expediçāo ao Brasil, sob o comando do almirante 
Roussin, "com o fim único de fazer o levantamento matemático da costa..."(25). E E que revelando agudo faro político, Luiz XVIII desejava facilitar a navegaçāo entre a França e o Brasil, "porque estava certo", afirma Gallès, "de que êste pais, em vésperas de realizar sua revoluçāo, poderia oferecer, no futuro, esccadouros imensos nāo só às nossas manufaturas como à nossa indústria". O autor da Carta já tinha, aliás, no que apoiar suas . conclusões: "Político profundo, grande administrador, êle previa que a exemplo. da República Argentina, o Brasil, sacudindo o jugo da metrópole, elevando um templo à liberdade sôbre as ruinas da escravidāo, tornando-se livre, enfim, para escolher suas relações comerciais e obter os objetos de seu consumo, deveria, sem dúvida, voltar seus olhos para a França, para à satisfaçāo das necessidades de seu luxo e de sua vida animal, necessidades estas que acompanham sempre de perto uma naçāo que se liberta, e que sāo o efeito inevitável da introduçāo das ciências e das artes entre os povos".

E confirmando a observaçăo feita por quase todos os viajantes, sôbre os costumes brasileiros da época, acrescentava Gallès: "O consumo (de mercadorias), que me parece digno, desde já, de merecer cuidadosa atençāo, quer do govêrno, quer do comércio francês, se ressente necessàriamente, ainda hoje, do costume antigo que năo permite às mulheres destas regióes ver a luz do dia senāo do interior de suas casas".

Mas na ocasiāo em que nosso viajante aqui esteve, outro entrave seríssimo embaraçava as relações mercantis do Império: "A guerra obstinada com Buenos Aires e que eu considero interminável", ponderava Gallès com grande propriedade, "enquanto o Brasil pretender conservar as mesmas pretensões sôbre a Provincia Cisplatina, pois que o orgulho e a ambiçāo falam sempre mais alto do que a sabedoria e a moderação entre os homens; a querra, repito, golpeia também rudemente o comércio do Rio de Janeiro e do Brasil em geral; cada dia que passa conta com o apresamento, mais ou menos ${ }_{\boldsymbol{\mu}}$ numeroso, de embarcações e navios pertencentes aos brasileiros;' e nāo raro a capital nēo pode atender às necessidades de sua exportação, pois os proprietários das mercadorias têm receio de ser aprisionados durante a pequena navegaçāo, que são obrigados a fazer de suas plantações à cidade. Este estôrvo

(25). - Estáa expedição, que teve início em 1819, durou 19 meses. o levantamento realizado compreendeu 900 léguas de costa, ou seja, de Santa. Catarina a São Tuiz do Maranhão. Sel autor que, dada a importância de seu trabalho, foi distinguido pelo rei da Franca $\mathrm{com}$ o título de barão e condecorado por $D$. Pedro $X$ com a comenda do Cruzeiro, publicou suas observaçōes nessa obra sumamente árida. "Le Pilote du Brésil ou Description des Cótes de l'Amerique Meridionale. comprises entre l'lle Santa Catarina et celle de Maranhão avec les instructions necéssaires. pour atterir et naviguer sur ces côtes", París, Imprimerie Royale, 1828. Ver "Biographie de l'Amiral Baron Roussin: 1781-1854", París, 1892. 
acarreta amiude a carestia dos gêneros, a qual, por sua vez, provoca inevitável alta de preços"(26).

O tráfico de escravos, ainda entāo intensissimo, apesar das medidas repressoras adotadas pela Inglaterra, foi a coisa que mais feriu a sensibilidade de Gallès, no Rio de Janeiro. "E comum", dizia êle, "ver chegar navios negreiros com quinhentos a seiscentos escravos, comprimidos uns contra os outros, como o gado que os nossos carniceiros enviam ao corte. Estas inocentes vítimas da civilizaçāo sāo trocadas e adquiridas exatamente com as mesmas formalidades que os nossos animais na Europa". E Gallès continuava, revoltado: "Et il faut rougir de porter le nom d'homme quand on entende dire à un Brésilien: "Je donnerais $100 \mathrm{fr}$. de flus de cet homme, s'il était plus gras, et qu'il eût l'oeil plus animé...". E para dar prova de seus conhecimentos lingüísticos, apressava-se a aduzir, na lingua original, parte da frase que tanto - havia ferido: "Eu dacare 16.000 réis de mas por êsse homem, sc me paresse mats gorde". . Era o espetáculo dos leilões de escravos, com o seu cortejo de horrores, onde o observador de melhores sentimentos ficava em dúvida se devia chorar ou rir, quando ouvia "o charlatāo" gritar com todo sangue frio (e aqui vai a frase no português insólito de Gallès): "Pois enton seignors, coragem. a 130.000 réis homem".

E contra tal ignomínia clamava o autor de "Du Brésil", lamentando que a História tivesse de dar conhecimento dêsses sacrilégios à posteridade, que dificilmente poderia acreditar que êles houvessem tido lugar nos dominios de reis cristāos, e num século em que as ideias de liberdade abrasavam os homens nos dois hemisférios (27).

(26). - O tratado preliminar de paz entre o Brasil e a Argentina foi assinado en 27 de agôsto de 1\$̣2R. Gallès observa, aliăs. em nota an pé da página. que. na ocasiāo em que seu livro se encontrava no prelo, anunciavam os jornais o termino das hostiliclades entre os dois países. to de surpreender que no comentário, que acima transcrevenos, ele não fiz.esse qualquer referéncia ao apresamento dos navios mercantes franceses feito pelo Brasil. em virtude do bloqueio do Rio da Prata. fato que culminou com a entrada, no kio de Janeiro, de uma esquadra sob - comanda do Almirante Roussin, para apoiar o protesto da França. (Ver Joño Pandiá Calogeras, "A Política lixterior do Imperio, vol. II. Rio de Janeiro, 1928, págs. 441-4t2; Alberto Rangel, "Trasanteontem", Sĩo Paulo, 1943, págs. 207 e seguintes: Baräo do Rio-IBranco, "Lfemérides Brasileiras", Rio de Taneiro, 1946, páss. 314-15).

(2T). - Se muitos sĩo os depoimentos de viajantes estrangeiros sobre a triste condicão dos escravos no I3rasil, não faltam, tamhem, os dos que a pintaram com cores mais róseas, como Ferdinand Dinis, ao tra.tar da Bahia. na parte que the coube no livro escrito de parceria com Hippolyte Taunay (op. cit., pág. 03); C. Schlichthorst ("O Rio de Janeiro 
E Gallès aduzia, com uma eloqüência à altura de nossos futuros abolicionistas: "É em vāo que penas venais tentarāo provar que êste tráfico infame é um mal necessário à prosperidade do país em que êle se opera; é em vão que, por meio de principios especiosos ou de sofismas dignos de séculos bárbaros, procurarāo insinuar-nos que, por causà do pequeno movimento emigratório de europeus para o Brasil, êste país, desprovido de fôrça numérica, está reduzido à cruel necessidade de saquear os silenciosos e selvagens desertos da Africa, para ter braços... Braços?... Insensâtos! Para que servem êstes braços presos nas cadeias da servidāo?".

Os danos que a escravatura causava a uma sociedade indolente, acostumada a nada fazer (28), e de que outros viajantes pintaram curiosos aspectos, não escapariam, também, à sua atilada percepção: " $E$ vós, classe ociosa, que repousais inteiramente sôbre o trabalho dêstes infelizes, para a satisfaçāo das necessidades de vossa vida animal, vós desconheceis o mal involuntário que vos causam vossos escravos; vós esqueceis que a máquina melhor combinada, o mecanismo mais perfeito, que ficam em contínua inatividade acabam por estragar-se um dia; vós esqueceis que os serviços e trabalhos, que exigis de vossos escravos, se ressentem sempre de sua estupidez e de seu barbarismo; vós esqueceis que poderieis fazer numa hora o que êles fazem, imperfeitamente, num dia; e vós nāo refletis que, deixando tudo a cargo dêles, perdeis em energia e em indústria o que êles ganham na proporção de suas faculdades".

E Gallès terminava, confiante na futura emancipaçāo da raça negra: "Mais c'est assez: détournons les yeux d'un tableau dont les couleurs sinistres doivent soulever tous lès coeurs généreux; et espérons enfin que le progrès des lumières excitera un jour chez ces victimes l'usage du sens commun que la nature a placé dans le cerveau de tous les hommes, et qu'en acquérant peu à peu le sentiment de leurs forces, ils finiront par se faire admettre dans la grande famille des nations, en marchant à l'aide d'un flambeau

como e. 1824-1.826", trad. de Emmy Dodt e Gustavo Barroso, Rio de Taneiro, s/d, pág. 132): Joảo Maurício Rugendas ("Viagem Pitoresca através do Brasil", trad. de Sérgio Milliet, 4.a ed., São Paulo, 1949, págs. 167-177): Henry Koster (op. cit., págs. 493 e seguintes) ; George Gardner ("Viagens no Erasil... durante os anos de 1836-18+1", trad. de Albertino Pinheiro, S. Paulo, 19.12); Francis Castelnau ("Gxpedicão às Regiões Centrais da América do Sul"', trad. de Oliverin M. de Oliveira Pinto, São Paulo, 1949, pág. 79). Ảlguns dêles chegaram a afirmar que a situação dos escravos no Brasil era nuito mais humana do que nos estabelecimentos franceses e inglêses dus Antilhas.

(28). - Caio Prado Junior, em seu livro "Formaçĩo do Brasil Contemporaneo". escreve: "Assim, no campo como na cidade, no negócio como em casa, o escravo é onipresente. Torna-se muito restrito o terreno reservado ao trabalho livre, tal o poder absorvente da escravidão. E a utiliza.ção universall do escravo nos vários misteres da vida económica e social acaha reagindo sobre o conceito do trabalho, que se torna ocupação pejorativa e lesabonadora" (pg. 277). 
peut-être moins animé que le nôtre, mais conduisant au même but par des sentiers plus obscurs...".

$\mathrm{Na}$ opiniāo de Gallès, a constituiçāo do Brasil era "a mais liberal, a mais democrática das constituições contemporâneas", esclarecendo êle, no que demonstrava andar bem informado, que seus primeiros fundamentos haviam sido estabelecidos pelos Andradas, "cujas virtudes, talento e patriotismo" todo o mundo conhecia. E sem fazer, porém, qualquer menção às lutas já entāo em plena efervescência entre o absolutismo de Pedro I e o liberalismo de que o melhor pregador era Evaristo da Veiga, em sua folha "Aurora Fluminense", e que viria a culminar com a revoluçāo de abril de 1831, anotava: "La liberté civile, religieuse et commerciale au Brésil, est digne de l'envie des peuples les plus policés. Le Brésilien a le droit de tout dire, tout écrire; sa croyance est subordonnée au sentiment de sa conscience, et les prêtres se garderaient bien d'en violer l'asile sacré...".

Esclarecia o nosso viajante, a seguir, dentro da mesma ordem de idéias, que o brasileiro era livre de transportar seus vinhos, suas mercadorias para o lugar que quizesse, sem que o govêrno lhe cobrasse um real. "Penso mesmo", continuava êle, "que será impossivel impor no Brasil direitos reunidos" - e aqui enganava-se redondamente sôbre o nosso sistema fiscal - "tais como, licença, patente, sêlo, registro, etc., sem uma revoluçāo, tanto me acho convencido da maneira como estas mentes vulcânicas estão imbuidas das idéias de liberdade!"(29)

(29). - Ferto que uma das causas principais de algumas das revoluçóes ou motins havidos no Brasil foi a opressão fiscal. Nãn tiveram elas a virtude. porém. de corrigir $n$ desordenado sistema tributário, quex do Brasil Colonia. quer do Brasil Imperio. Abŕs a chegada de D. Toão VI, multiplicaram-se os impostos gerais. nĩo ram sob as mais extranhas figliras. poraluanto os Aircitos de importactoo, que naturalmente constituiam a maior fonte de receita. lonfe estavam de satisfazer as crescentes necessidades do erário. "A taxa de trânsito entre as províncias. alkm de omerosissima". diz Antônio Carlos Ribeiro de Andrada, “variava de província em província. salvo por via marf́tima. Năo số ela. como a de siza. os dizimos e o jmposto de ouro longe de produzirem. por excessivamente pesados. os rendimentos que. se mais módicas, determinariam, constituiam formidavel embaraço an desenvolvimento economico da colonia. cuja capacidade tributária por isso mesmo acentuadamente definhava. A tão defeituoso p arbitrário regime de impostos. evidentemente incompativel $\mathrm{com}$ a prosperidade de rendas. acrescia a viciosa organização fiscal, cujos aparelhos de arrecadaç̃̃o e fiscalizacão funcionavam irregular e frouxam^nte ("O Ministro da Fazenda da Independencia", separata da "Revista do Instituta Histórico Brasileiro". Iivraria T. Jeite, Rio de Janniro, pág. 36\%).

A Constituicão do Imperio. de 25 de março de 1824 . consagrara em seu artigo 179, n.0 15, adiantado princípio fiscal: "Ninguén será isento de contribuir para as despesas dn Estado, em proporção dos seus haveres'. Tal princípio que. a ser observado. implicaria na reforma completa do sistema tributário então viǵente, ficou, comó não podia deixar de ser. apenas na letra. da lei.

fí. de se notar ainda, que an criar em cada. Prnvíncia um Conselho Geral (art. 72), não conferiu a Carta Magna a esses orgãos com- 
O direito penal brasileiro, que se ressentia ainda, ao tempo em que Gallès aqui esteve, do sarro das Ordenações Filipinas, nāo obstante os avançados principios estabélecidos na Constituição de 1824, mereceu, também, alguns comentários sôbre a sua imperfeiçāo. Mas, nessa época, já estava sendo discutido o importante projeto apresentado em 1827 por Bernardo Pereira de Vascóncelos, o "Mirabeau do Brasil", no dizer de Armitage(30), projeto êsse em que iria apoiar-se inteiramente o Código Criminal, aprovädo em $1830(31)$.

petência pára legislar sôbre imposiçōes, cuja iniciativa era atribuicão exclusiva da Câmara dos Deputados (art. 36). E a lei orçamentária de 24 de outubro de 1832 e que dividiu, pela primeira vez, a receita pública. em geral e provincial. Depois de especificar, em seu artigo 78 . os impostos da receita geral, estabelecia no artigo 83: "Pertencem à receita provincial todos os impostos ora existentes não compreendidos na receita geral".

Reformada a Constituição pela lei de 12 de agósto de 1834 (Ato Adicional), as Assembleias Legislativas Provinciais, que substituiram os Conselhos Gerais. podiam Jegislar "sôhre a fíxação das despesas municipais e provinciais. e os impostos para elas necessários" conquanto que êstes não prejudicassem as imposiçôes gerais do Estado (art. 10, n. $\mathrm{V}$ ). As mesmas assembleias era defeso legislar sobre impostos de importaçan (art. 12).

Foi a lei de orçamento de 31 de outubro de 1835 que, a seguir, fixou os impostos da receita geral e, consequientemente, por exclusão, os da receita provincial.

Mas os limites dessa partilha eram freqüentemente desrespeitados pelas Províncias que. à míngua de recursos, invadiam a esfera tributária do Poder Central. A propósito, merecen ser transcritas, pois reflefem bem o panorama fiscal do Brasil Império, as palavras da comissão encarregada em 1883 pelo Ministro da Fazenda, Conselheiro Lafayette Rodrigues Pereira, de "rever e classificar as rendas. gerais, provinciais e municipais do Império": "Ts uma verdade desconsoladora! Há quase meio século que vem incessantemente repercutir ante - Govêrno Central e ante o Parlamento o reclamo angustioso das Provincias do Imperio contra a partilha de impostos, que se lhes adjudicou no inventário, iulgado pela lei n.o 99 , de 31 de outubro de 1835. Essas numerosas pupilas acoimam de leonina a distribuicão do tutor, acusando $=0$ de abusar da tutela, pois lhes nega o essencial para satisfação de suas mais urgentes necessidades e as condena assim a debaterem-se em dolorosa penúria. Atribuem aos Poderes Gerais o seu atrazo, pois, sem meios de ação, destituidas dos recursos fecundadores de sua riqueza, manietadas no livre exercicio de suas fôrcas vivas por impedimentos, que não está em suas mãos remover. não podem marchar senão lenta e quase imperceptivelmente pela estrada incomensurầvel do progresso, nern desenvolver, na escala conveniente, todos os germens de grandeza e prosperidade, que encerram em seu grêmio. Talvez que êsse reclamo não seja plenamente justificado, e se dê exagêro em tais queixas; que de dia para dia se tornam mais intensas e freqiientes. Apreciada ì luz da crítica serena e imparcial a administração de algumas das Províncias, que mais alto erguem o brado, talvez se verifique, em parte, que é devido aos próprios erros, e principalmente à falta de economia, o desequilibrio entre a receita e a despesa, que se nota em seus respectivos Orcamentos" (Relatório e Projeto de Lei, Rio de Janeiro, Tipografia Nacional, 1883).

(30). - João Armitage, "História do Brașil", 3, edição brasileira com anotacões de Eugênio Egas e Garcia Junior. Rio. 1943. pág. 244.

(31). - Vejam-se as teses apresentadas à 5.a Secção (História Parlamentar) do. Yrimeiro Congresso de História Nacional, pelos.Jrs. Alfredo Pinto Vieira de Mello, Virgilio de Sá Pereira e Helvécio Carlos da Silva Gusmão ("Revista do Instituto Historico e Geographico Brasileiro" tomo especial, parte IV, Rio de Janeiro, 1916) : o estudo do Prof. Waldemar Ferreira, "O centenário do Código Comercial", in "Revista da Faeuldade de Direito", da Universidade de Minas Gerais, de outubro de 1950, bem como a memória publicadà pelo Dr. Júlio de Barros Raja Gabaglia. sob o título "As ciências jurídicas e sociais", no Livro do Centenário, IIJ. Rio de Ianeiro. 1902. 
Fêz referência, também, o autor de "Du Brésil" aos cursos jurídicos criados em Olinda e Sāo Paulo, que êle situou, entretanto, "nos arredores do Rio de Janeiro"; à biblioteca e ao museu da Capital, observando que o amor que a mocidade demonstrava pelo estudo era qualquer coisa de incomum; parecia que "ela, envergonhada de sua ignorância, sentia a necessidade de reparar, por tum trabalho perseverante e consciencioso, o tempo perdido na apatia e obscuridade".

A riqueza das igrejas no Brasil, com suas imagens e candelabros de prata e ouro maciços, foi outra coisa que causou pasmo. a Gallès. As cerimônias religiosas pareceram-lhe de uma pompa e magnificência extraordinárias, embora pensasse que mais valeria aplicar as somas imensas despendidas com as procissões "no reparo das estradas e canais que se encontram num estado lamentável" (32). E nunia frase, apenas, sintetiza com grande fidelicảade o modo de ser do brasileiro perante a religiāo: "Le Brésilien observe tout le décorum et l'exterieur du catholicisme, mais il n'est pas foncièrement religieux" (33).

Entretantó, é ao delinear outros traços do caráter brasileiro que Ed. Gallès se mostra mais impreciso, embora dê provas de bom psicólogo, em algumas de suas observações. Começa êle por afirmar: "Os brasileiros sāo fúteis, presunçosos, mas leais, bons negociantes e muito francos nos negócios. Ligam-se dificilmente a ı!m estrangeiro." Mas continua implacável: "Atrazados em civilizaçāo, com todo o exterior da gravidade anglicana e a fleugma do saber germânico, êles são, no entanto; profundamente ignorantes. 'Os sentimentos de bravura e de patriotismo lhes sāo desconhecidos, uma vez que estas virtudes sāo o efeito necessário e inediato da educaçāo nos homens."

(32). - O Desembargador João Rodrigues de Britto, ao referir-se, em 1821, ao malu estado dos caminhos no Recôncavo da Bahia, observava com o mesmo espirito objetivo: "Bastaria a despesa que se gasta numa procissão para fazer desaparecer todas essas ladeiras" (Gilberto Freyre, "Nordeste", 2," ed., IRio de Janeiro, 1951, pág. 129)

(33). - Freycinet. anos antes. já se escandajizara com a falta de piedade com que os brasileiros se portavam no templo: "Assisti um dia a uma festa religiosa que teve Iugrar na igreja de Santa Luzia. se é que se pode dar esse nome a uma reunião considerável de pessoas que parecem ter-se reunido no lugar santo apenas pare ver e ser vistas e ouvir boa música,". Menos amável é a observação que mais tarde seu compatriota, Abel Du Petit Thouars, faria sôbre o mesmo assunto: "As procissões religiosas são freqüentes, no Rio de Janeiro, feitas com grande pompa. Os assistentes são sempre muito numerosos, porque a população em geral, infelizmente muito depravada e pouco religiosa, atem-se sobretuclo à observância das formas do culto externo" (Apud C. de Mello Leitão, "Visitantes do Primeiro Imperio", São Paulo, 1934, pá.gs, 131 e 133 ).

O testemunho de Jean Baptiste Debret, em sua "Viagem Pitoresca e Histórica ao Brasil", na parte em que trata da "Fducac̃̃o das muiheres" e "Culto religioso" não desmente o que os demais viajantes afirmaram neste sentido. 
Esta última afirmativa encontra-se, para consôlo nosso, em flagrante contradiçāo com o amor desenfreado pela liberdade que, logo adiante, Gallès atribui aos brasileiros: "La politique de tout Biésilien se renferme dans le mot liberté... Sans connaître les Bossuet et les Royer-Collard, ils établissent qu'il n'y a pas de droit au-dessus de leur droit, et qu'aucune puissance humaine ne peut dépasser de leur volonté" (34). A liberdade é a deusa que os brasileiros cultuam, "é o ídolo diante do qual se prosternam religiosamente, é por ela que seriam capazes de provar um dia, àquêles que tentassem roubar-lha, que uma naçāo sem fôrça nem espirito belicoso, sem gênio nem tática militares, pode encontrar todos êsses elementos de poderio na firme e unânime vontade de repelir a servitude e a tirania".

Embora comente o assunto com aparente bom humor, nada deve ter irritado mais o nosso viajante do que a gabolice dos brasileiros, que, pelo seu testemunho, se julgavam superiores aos franceses, por um raciocinio muito simples: "Nós", diziam êles, "somos filhos de Portugal, que bateu a Espanha; logo se esta venceu os franceses...". Ou, em outras palavras, segundo a pitoresca transcriçāo de Gallès: "Nos estamos os vencedors do vencedor das vencedors!"

Daí, talvez, a pressa com que êle acrescenta: "A inveja, que aliada ao orgulho, é a pedra de toque do caráter brasileiro, conduze-os (os brasileiros), freqüentemente, a atos de crueldade e de desespêro".

Nāo discrepam das narrativas de outros viajantes da época, $e$ até de tempos bem posteriores, as ligeiras observações que 0 nosso autor faz, também, a respeito da vida social no Brasil. Nada de passeios, nem divertimentos. Se havia, de vez em quando, e por circunstâncias extraordinárias, algumas reuniões, as mulheres, que nāo saiam à rua senäo para ir à igreja e ao teatro, eram delas excluidas(35). Mas, mesmo assim, as representantes do sexo fraco

\footnotetext{
(34). - As palavràs em itálico, nesta transcrição, encontram-se assim no original.

(35). - Muitos anos depois da visita de Gallès ao Brasil, Elizabeth Cary Agassiz ainda anotava em seu diărio de viagem: "Efetivamente, nunca conversei com as senhoras com quem de mais perto privei no Brasil que delas não recebesse as mais tristes confidências acêrca de sua existência estreita e confinada. Não há só uma brasileira, que tenha um pouco refletido sôbre o assunto, que não se saiba condenada a uma vida de repressóes e constrangimentos. Não podem transpor as portas de sua casa. senão em determinadas condicoes. sem provocar escândalo. (...) Mesmo quando as brasileiras tenhan recebido os benefícios da instrucão, há, em sua existência doméstica, tanta compressão, elas estão tão pouco em ligação com o mundo exterior, que isso basta para por um obstáculo ao seu desenvolvimento intelectual; os seus prazeres são tão mesquinhos e raros como os seus meios de instrução" (Luiz Agassiz e Elizabeth Cary Agassiz, "Viagem ao Brasil - 1865-1866", trad. de Edgar Sussekind de Mendonça, São Paulo, 1938, págs. $569-70)$.
} 
nāo deixaram de causar-lhe forte impressāo:" "quoique très brunes, elles y sont d'une beauté rare; mais à peine le bouton a-t-il paru que la rose commence à se flètrir!...".

$\mathrm{E}$ ao encerrar estas primeiras considerações sôbre o Brasil, com um apêlo lírico aos seus concidadãos para que soubessem sacrificar, em qualquer tempo e em qualquer lugar em que se encontrassem, a causa individual pela causa comum, Gallès escrevia com uma ponta, talvez, de falsa modéstia: "Eis, sucintamente, as idéias gerais que julguei dever pôr à testa de meu trabalho; elas ai estāo, evidentemente, sem ordem e sem arte; mas repito, mais uma vez, que estou escrevendo para o comércio e nāo para a Academia; dou-me por satisfeito se me fiz entender, pois nāo tenho dúvida de haver rompido um silêncio vantajoso para alguns interêsses particulares, mas prejudicial aos interêsses da coletividade". $\mathrm{E}$ isto com uma grande barretada, coisa em que Gallès viria a tornar-se mestre, ao sucessor de Luiz XVIII: "De quelque classe, de quelque rang que vous puissiez être dans la société, faites parvenir vos avis jusque sur les marches du trône, ils y seront accueillis par un roi sage et constitutionnel, que, satisfait de l'éclat de sa couronne, ne demande au Ciel d'autre félicité que la gloire et le bonheur de ses sujets".

(Continua no próximo número) 